\title{
Babesiosis of wild carnivores and ungulates
}

\author{
Banie L. Penzhorn
}

\begin{abstract}
Although large and small piroplasms have been reported from various wild carnivore and ungulate species, relatively few have been named. In the past, mere presence of a piroplasm in a specific host frequently prompted naming of a new species. Descriptions were often inadequate or lacking altogether. Currently, demarcation of species relies heavily on molecular characterisation. Even serological evidence is deemed insufficient. Experimental transmission of Babesia spp. from domestic to wild animals is usually only successful in closely related species, or after splenectomy. There are indications that endemic stability, similar to the situation in livestock, is the general pattern in Babesia sp. infections in wildlife. All lions in Kruger National Park were found to be infected with $B$. leo, which did not lead to clinical disease manifestation in artificially infected lions. Under stressful conditions, infections could flare up and be fatal, as purportedly happened to the famous lioness "Elsa”. Similarly black rhinos, which can harbour Babesia bicornis without ill effects, may develop clinical babesiosis during confinement after capture. Zoo-bred animals, which were not exposed to Babesia spp. at a young age, may be fully susceptible when released into a natural environment where other members of their species occur. This could have major implications for ex situ conservation programmes aimed at bolstering natural wildlife populations.
\end{abstract}

\section{Article Outline}

1. Introduction

2. Babesia species described from wild carnivores and ungulates

3. Babesia species of domestic animals occurring in wildlife

4. Effect of Babesia infections in wild animals

5. Potential impact of Babesia infections on conservation actions

6. Conclusions

References 


\section{Introduction}

Large and small piroplasms have been reported from various wild carnivore and ungulate species. The reports frequently are mere documentations of organisms seen on blood smears randomly made of clinically normal animals. In a minority of cases, these organisms are incriminated as causing diseases in their hosts. In most cases, the organisms are not named.

There has also been a plethora of names under which these organisms are reported. Some small piroplasms may also have been recorded as Theileria species, based on morphology. Wenyon (1926) discarded the genus names Piroplasma, Nicollia, Nuttalia, Smithia, Rossiella, Babesiella and Microbabesia in favour of a single genus, Babesia. He even included Gonderia, now regarded as a synonym of Theileria, in this group. Levine, 1971 and Levine, 1988 basically followed the same approach. It is becoming apparent that this classification is an oversimplification. Splitting is probably imminent, and some of the discarded genus names may have to be resurrected.

In contrast to the rather informal descriptions of the past, demarcation and definition of species has become much more rigorous and relies heavily on molecular characterisation. Even serological evidence is deemed insufficient (Lopez-Rebollar et al., 1999). Few new Babesia species have been described in recent years.

\section{Babesia species described from wild carnivores and ungulates}

In the past, mere presence of a piroplasm in a specific host frequently prompted naming of a new species. Descriptions were often inadequate by today's standards, or lacking altogether. In the absence of reference type material, it is often virtually impossible today to determine the identity of many of these organisms with any degree of certainty.

The Babesia species named from carnivores and ungulates are given in Table 1 and Table 2, respectively. The current taxonomic status of several of these entities is uncertain. In a survey of haemoparasites of free-ranging ruminants in Austria, Hinaidy (1987) questioned the validity of several species, including Babesia moravica, Babesia capreoli and Babesia odocoilei.

Table 1.

Babesia spp. described from wild carnivores

\begin{tabular}{|l|l|l|}
\hline Species & Host & Author(s) and year \\
\hline Family Canidae (dogs) & Leger and Bédier (1922) \\
\hline B. bauryi $^{\text {a }}$ & Fennecus dorsalis & Nuttall (1910) \\
\hline B. (canis) rossi & Canis adustos & Yakimoff and Shokor (1916) \\
\hline B. & Canis lupus & \\
\hline
\end{tabular}




\begin{tabular}{|c|c|c|}
\hline Species & Host & Author(s) and year \\
\hline \multicolumn{3}{|c|}{$\begin{array}{l}\text { ninakohlyakimo } \\
\text { vae }\end{array}$} \\
\hline B. procyoni & Nyctereutes procyonides & Chobotar'ov (1938) \\
\hline \multicolumn{3}{|c|}{ Family Felidae (cats) } \\
\hline B. catus & Felis catus & Mudaliar et al. (1950) \\
\hline B. felis & Felis ocreata (= F. sylvestris) & Davis (1929) \\
\hline B. herpailuri & Herpailurus yaguarundi & Dennig (1967) \\
\hline B. leo & Panthera leo, P. pardus & Penzhorn et al. (2001) \\
\hline B. pantherae & Panthera pardus & Dennig and Brocklesby (1972) \\
\hline \multicolumn{3}{|c|}{ Family Herpestidae (mongooses) } \\
\hline B. cynicti & Cynictis penicillata & Neitz (1938) \\
\hline B. heischi & $\begin{array}{l}\text { Helogale undulata rufula (?H. } \\
\text { parvula) }\end{array}$ & Grewal (1957) \\
\hline B. herpestidis & Herpestes ichneumon & França (1908), in Levine (1988) \\
\hline B. hoarei & Helogale undulata rufula & Grewal (1957) \\
\hline B. legeri & $\begin{array}{l}\text { Herpestes calera (?Atilax } \\
\text { paludinosus) }\end{array}$ & $\begin{array}{l}\text { Bédier (1924); Penzhorn and } \\
\text { Chaparro (1994) }\end{array}$ \\
\hline B. mungo & $\begin{array}{l}\text { Herpestes mungo (?H. } \\
\text { edwardsi) }\end{array}$ & Carpano (1939); Levine (1984) \\
\hline B. vanhoofi & Helogale varia (?H. parvula) & De Smet and Lips (1955) \\
\hline \multicolumn{3}{|c|}{ Family Hyaenidae (hyaenas) } \\
\hline B. alberti & Crocuta crocuta & Van den Berge (1937) \\
\hline Fam Mustelida & veasels, badgers, polecats, etc.) & \\
\hline
\end{tabular}




\begin{tabular}{|l|l|l|}
\hline Species & Host & Author(s) and year \\
\hline B. meles & Meles meles & Krivkova (1960) \\
\hline B. mephitis & Mephitis mephitis & Holbrook and Frerichs (1970) \\
\hline B. missirolii & Meles meles & Biocca and Corradetti (1952) \\
\hline B. mustelae & Mustela putorius & Lebedeff and Tscharnotzky (1911) \\
\hline B. roubaudi & Ictonyx striatus & Leger and Bédier (1923) \\
\hline \multicolumn{2}{|l|}{} \\
\hline Fam Viverridae (civets, genets, etc.) & \\
\hline B. civettae & Civettictis civettae & Leger and Leger (1920) \\
\hline B. garnhami & Genetta genetta; Genetta tigrina & Heisch (1952) \\
\hline B. genettae & Genetta genetta & Heisch (1952) \\
\hline \multicolumn{2}{|l|}{} \\
\hline Family Procyonidae (raccoons) & Anderson et al. (1981) \\
\hline B. lotori & Procyon lotor &
\end{tabular}

${ }^{a}$ Regarded as a synonym for B. gibsoni by Levine (1988); Fenecus dorsalis is regarded as a synonymn for Canis aureus dorsalis (Maronpot and Guindy, 1970).

Table 2.

Babesia spp. described from wild ungulates

\begin{tabular}{|l|l|l|}
\hline Species $\quad$ Host(s) & Author(s) and year \\
\hline Order Perissodactyla, Family Rhinocerotidae (rhinoceroses) & Nijhof et al. (2003) \\
\hline B. bicornis $\quad$ Diceros bicornis & \\
\hline \multicolumn{2}{|l|}{} \\
\hline Order Proboscidea (elephants) & Rodhain (1936) \\
\hline B. loxodontis & Loxodonta africana & \\
\hline
\end{tabular}




\begin{tabular}{|l|l|l|}
\hline Species & Host(s) & Author(s) and year \\
\hline Order Hyracoidea (hyraxes) & \multicolumn{2}{l|}{} \\
\hline B. thomasi & Procavia capensis, P. habessinica, Dendrohyrax brucei & $\begin{array}{l}\text { Jansen (1952); Levine } \\
\text { (1988) }\end{array}$ \\
\hline \multicolumn{2}{|l|}{} \\
\hline Order Artiodactyla, Family Bovidae (buffaloes, wild sheep, goats and antelopes)
\end{tabular}

Some piroplasms from wild carnivores and ungulates were described under other genera, e.g. Piroplasma, Nuttalia and Nicollia. Molecular characterisation is sorting out some of the uncertainty, but a lot remains. For instance, the species currently regarded as Theileria equi (Mehlhorn and Schein, 1998) and initially described as Piroplasma equi (Laveran, 1901), was long regarded as a Babesia species. It has been classified under at least seven other genera. Current indications are that the small Babesia spp., primarily those isolated from rodents and felids, may be ancestral to the whole Babesia/Theileria complex (Penzhorn et al., 2001). The use of the genus name Babesia for this cluster of species should therefore be reconsidered.

Unidentified piroplasms have been recorded from various other wild carnivores and ungulates (Table 3). An unnamed Babesia from the North American elk (Cervus elaphus) has been isolated in culture and partially characterized (Holman et al., 1994). Two Babesia spp. isolated from mule deer (Odocoileus hemionus) and bighorn sheep (Ovis canadensis) in California, USA, have been 
cultured and seroprevalence determined, but the species have not been named (Kjemtrup et al., 1995). Prevalence reached $60 \%$ in some areas. One of these isolates has been partially characterized (Goff et al., 1993).

Table 3.

Unnamed Babesia spp. reported from carnivores and ungulates

\begin{tabular}{|l|l|}
\hline Host & Author(s) and year \\
\hline Carnivores & \\
\hline Family Felidae (cats) \\
\hline Acinonyx jubatus & Averbeck et al. (1990) \\
\hline Lynx rufus & Wenyon and Hamerton (1930) \\
\hline Panthera pardus & Brocklesby and Vidler (1965) \\
\hline Panthera tigris & Nagar et al. (1979) \\
\hline \multicolumn{2}{|l|}{} \\
\hline Family Hyaenidae (hyaenas) \\
\hline Proteles cristatus & Peirce et al. (2001) \\
\hline \multicolumn{2}{|l|}{} \\
\hline Family Viverridae (mongooses) \\
\hline Galerella sanguinea & Penzhorn and Chaparro (1994) \\
\hline Mungos mungo & Penzhorn and Chaparro (1994) \\
\hline \multicolumn{2}{|l}{} \\
\hline Ungulates \\
\hline Order Perissodactyla (odd-toed ungulates) \\
\hline Ceratotherium simum & Bigalke et al. (1970) \\
\hline \\
\hline Order Proboscidea (elephants) \\
\hline Loxodonta africana & Brocklesby and Campbell (1963) \\
\hline
\end{tabular}




\begin{tabular}{|c|c|}
\hline Host & Author(s) and year \\
\hline \multicolumn{2}{|c|}{ Order Artiodactyla: Family Giraffidae (giraffes) } \\
\hline Giraffa camelopardalis & Brocklesby and Vidler (1965) \\
\hline \multicolumn{2}{|c|}{ Family Bovidae (wild sheep, antelopes and buffaloes) } \\
\hline Hippotragus equinus & Wilson and Hirst (1977) \\
\hline Ovis canadensis & Goff et al. (1993); Thomford et al. (1993) \\
\hline Tragelaphus scriptus & Bigalke et al. (1972) \\
\hline \multicolumn{2}{|l|}{ Family Cervidae (deer) } \\
\hline Cervus elaphus & Holman et al. (1994) \\
\hline Odocoileus hemionus & Thomford et al. (1993); Kjemtrup et al. (2000) \\
\hline Rangifer tarandus & Holman et al. (2002) \\
\hline
\end{tabular}

\section{Babesia species of domestic animals occurring in wildlife}

The Babesia species of domestic carnivores and ungulates reported from wildlife are listed in Table 4. Not surprisingly, these shared Babesia spp. occur in hosts that are closely related to each other. Examples of these are Babesia trautmanni from the domestic pig and the wild boar, but also from African bushpig Potamochoerus porcus and warthog Phacochoerus aethiopicus, and Babesia caballi and Babesia equi from various zebra species.

Table 4.

Babesia spp. recovered from both domestic animals and wildlife

\begin{tabular}{|l|l|l|l|}
\hline $\begin{array}{l}\text { Domest } \\
\text { ic host }\end{array}$ & $\begin{array}{l}\text { Babesia } \\
\text { species }\end{array}$ & Wildlife host & Author(s) and year \\
\hline$\underline{\text { Horse }}$ & B. caballi & $\underline{\text { Equus burchelli }}$ & $\underline{\text { Neitz (1965) }}$ \\
\hline & & $\underline{\text { Equus zebra }}$ & Zweygarth et al. (2002) \\
\hline
\end{tabular}




\begin{tabular}{|c|c|c|c|}
\hline $\begin{array}{l}\text { Domest } \\
\text { ic host }\end{array}$ & $\begin{array}{l}\text { Babesia } \\
\text { species }\end{array}$ & Wildlife host & Author(s) and year \\
\hline \multirow[t]{3}{*}{ Donkey } & B. equi $^{\mathrm{a}}$ & Equus burchelli & Neitz (1931) \\
\hline & & Equus grevyi & Dennig (1966) \\
\hline & & Equus zebra & Young et al. (1973) \\
\hline \multirow[t]{6}{*}{$\underline{\text { Cattle }}$} & B. bigemina & Syncerus caffer & $\underline{\text { Karbe et al. (1979) }}$ \\
\hline & & Bison bison & Zaugg and Kuttler (1987) \\
\hline & & Mazama americana & Clark and Zetek (1925) \\
\hline & & Odocoileus virginianus & Clark and Zetek (1925) \\
\hline & & Gazella soemmeringi & $\begin{array}{l}\text { Enigk and Friedhoff, 1963a and } \\
\text { Enigk and Friedhoff, 1963b }\end{array}$ \\
\hline & & Hippotragus niger (?) & $\underline{\text { Hove et al. (1998) }}$ \\
\hline & B. bovis & Capreolus capreolus & Levine (1988) \\
\hline & & Cervus elaphus & $\underline{\text { Levine (1988) }}$ \\
\hline & & $\underline{\text { Odocoileus virginanus }}$ & $\underline{\text { Brumpt (1920) }}$ \\
\hline & & $\underline{\text { Bison bison }}$ & $\underline{\text { Salabarria et al. (1981) }}$ \\
\hline & B. divergens & Ovis musimon & Levine (1988) \\
\hline & & Cervus elaphus & Levine (1988) \\
\hline & & Dama dama & Levine (1988) \\
\hline & & Capreolus capreolus & Levine (1988) \\
\hline & & $\underline{\text { Rangifer tarandus }}$ & $\underline{\text { Nilsson et al. (1965) }}$ \\
\hline & B. major & Bison bison & Findlay and Begg (1977) \\
\hline Sheep & B. ovis & Capra pyrenaica & Ferrer et al. (1998a); Marco et al. \\
\hline
\end{tabular}




\begin{tabular}{|c|c|c|c|}
\hline $\begin{array}{l}\text { Domest } \\
\text { ic host }\end{array}$ & $\begin{array}{l}\text { Babesia } \\
\text { species }\end{array}$ & Wildlife host & Author(s) and year \\
\hline & & & $(2000)$ \\
\hline & & Ovis musimon & $\begin{array}{l}\text { Ferrer et al., 1998a and Ferrer et al., } \\
\underline{1998 b}\end{array}$ \\
\hline \multirow[t]{10}{*}{$\underline{\text { Dog }}$} & B. canis & $\underline{\text { Canis latrans }}$ & Ewing et al. (1964) \\
\hline & & $\underline{\text { Canis mesomelas }}$ & $\underline{\text { Neitz and Steyn (1947) }}$ \\
\hline & & Cyon dukhunensis & Leger and Bédier (1922) \\
\hline & & Nyctereutes procyonides & Levine (1988) \\
\hline & & Lycaon pictus & Neitz (1965) \\
\hline & & $\underline{\text { Vulpes vulpes }}$ & $\underline{\text { Schoop and Dedié (1938) }}$ \\
\hline & B. gibsoni & $\underline{\text { Canis aureus }}$ & $\underline{\text { Patton (1910) }}$ \\
\hline & & $\underline{\text { Canis latrans }}$ & Evers et al. (2003) \\
\hline & & Fennecus zerda & Maronpot and Guindy (1970) \\
\hline & & Vulpes vulpes & Maronpot and Guindy (1970) \\
\hline$\underline{\text { Cat }}$ & B. felis & Felis concolor & Carpano (1934) \\
\hline \multirow[t]{3}{*}{ Pig } & B. trautmanni & Potamochoerus porcus & $\underline{\text { Shone and Philip (1960) }}$ \\
\hline & & $\frac{\text { Phacochoerus }}{\text { aethiopicus }}$ & $\underline{\text { Stewart et al. (1992) }}$ \\
\hline & B. perroncitoi & $\underline{\text { Sus cristatus }}$ & Levine (1988) \\
\hline
\end{tabular}

${ }^{\text {a }}$ Regarded by some authors as Theileria equi (Mehlhorn and Schein, 1998).

It is not clear from the literature whether the identity of the Babesia sp. involved was confirmed in all cases, or whether the wildlife host's close relatedness to a domestic counterpart led to the 
assumption that the same Babesia sp. was involved. Caution should always be exhibited when making inferences about Babesia spp. from historical literature. In a recent publication (Hove et al., 1998) an unspoken inference is made that B. bigemina may have caused fatal babesiosis in a sable antelope. Rhipicephalus evertsi nymphs collected from the carcass of the sable antelope transmitted B. bigemina when allowed to feed on a bovine as adults. B. bigemina was not recovered from the carcass of the sable antelope. The authors do not indicate the locality involved, nor do they mention whether there were cattle in the vicinity. This is crucial information to bear in mind when interpreting the results of the study. The possibility exists that the $R$. evertsi ticks may have been the progeny of females engorging on cattle that carried $B$. bigemina. Transovarial transmission is known to occur (Büscher, 1988). The larvae attaching to the sable antelope could conceivably have been infected with $B$. bigemina. It should be noted that Thomas et al. (1982) attempted artificial infection of sable antelope with both B. bigemina and $B$. bovis, but were not successful.

Experimental infection of captive wild animals with Babesia spp. of domestic animals does not necessarily imply that their free-ranging counterparts would be susceptible. For instance, three captive African buffalo (Syncerus caffer) were injected with $5 \times 10^{9}$ bovine erythrocytes with $B$. bigemina, pathogenic for cattle (Karbe et al., 1979). None of the buffalo showed signs of disease, but Babesia were found in blood smears for 4 days indicating their multiplication. The carrier state of B. bigemina was established in two buffaloes for 28 and 147 days, respectively, by subinoculation into splenectomized calves, while no parasites were demonstrated 28 days after injection in the third buffalo. Two buffalo shot in Kenya did not appear to be carriers of $B$. bigemina, as shown by sub-inoculation of blood into splenectomized calves. Carmichael and Hobday (1975) found no Babesia spp. on blood smears of 190 African buffaloes in Northern Botswana. Karbe et al. (1979) speculated that African buffalo may play a role in the epidemiology of babesiosis in cattle, but any such role would probably be insignificant.

Two captive eland (Taurotragus oryx) were also inoculated with B. bigemina and their blood investigated as with the experimental buffalo (Karbe et al., 1979). Neither eland appeared to harbour B. bigemina 28 days after injection, even though one was splenectomized. B. bigemina could be established in a Soemmering's gazelle (Gazella soemmeringi) only after the recipient had been splenectomized (Enigk and Friedhoff, 1963a).

On the other hand, one spleen-intact and two splenectomized American bison (Bison bison) inoculated with $B$. bigemina stabilate exhibited clinical and hematological signs of babesiosis within 10 days of exposure (Zaugg and Kuttler, 1987). Redwater caused by B. major in a naturally infected captive American bison herd in the UK was confirmed serologically (Findlay and Begg, 1977), while a hemolytic process in bison was ascribed to B. bovis (Salabarria et al., 1981).

Wild animals may demonstrate clinical manifestation of babesiosis similar to that in domestic animals when placed in captivity in non-native areas. Reindeer (Rangifer tarandus) artificially infected with B. divergens (Nilsson et al., 1965) became anorectic and polypnoeic, and developed pale mucous membranes and hemoglobinuria. The authors noted that no disease suggestive of babesiosis was known to have occurred in reindeer in Sweden. The natural distribution of reindeer in that country does not coincide with the areas where bovine babesiosis is endemic. Furthermore, Ixodes ricinus, the vector of B. divergens, has never been recorded from Swedish 
reindeer. Fatal naturally acquired babesiosis, attributed to $B$. divergens infection, also occurred in a captive reindeer herd in the UK (Langton et al., 2003). Fatal babesiosis has been recorded in a captive American woodland caribou (Rangifer tarandus caribou) (Petrini et al., 1995). Serum from this animal cross-reacted strongly with $B$. bovis and $B$. divergens, and weakly with $B$. bigemina and B. odocoilei (see below).

B. bovis has been transmitted to white-tailed deer (Odocoileus virginianus), and has also been grown in vitro in white-tailed deer erythrocytes (Brumpt, 1920 and Holman et al., 1993).

Seroprevalences of antibodies against $B$. ovis of $12 \%$ and $32.6 \%$, respectively, were found in mouflon (Ovis musimon) and ibex (Capra pyrenaica) in Spain (Ferrer et al., 1998a and Ferrer et al., 1998b).

Coyotes (Canis latrans) artificially infected with B. gibsoni (Evers et al., 2003) developed a maximum parasitaemia of 8-11\% at weeks 3-4 after infection. Parasites were still detectable 20 weeks post-infection. B. canis rossi has been transmitted naturally and artificially to African wild dogs (Lycaon pictus) and black-backed jackals (Canis mesomelas) (Neitz, 1965, Neitz and Steyn, 1947 and Van Heerden, 1980). This parasite was originally described from a side-striped jackal (Canis adustos) (Nuttall, 1910). Fatal acute babesiosis has been recorded in a captive juvenile African wild dog (Colly and Nesbit, 1992).

\section{Effect of Babesia infections in wild animals}

The first report of clinical babesiosis in a wild animal may well be that of a fatal case in a wildcaught sable antelope (Hippotragus niger) in the Johannesburg zoo (South Africa), 6 weeks after arrival in mid-winter (Martinaglia, 1930). The condition was ascribed to reduced resistance following a change of environment and close confinement. The organism was later named $B$. irvinesmithi (Martinaglia, 1936).

An earlier report of piroplasmosis in reindeer by Kertzelli (1909; English translation in Chambers, 1921), who coined the name "Piroplasma tarandi rhangferis" for the causative organism concerned a Theileria sp. (Levine, 1971). The organisms are described as small, with cruciform division (Yakimoff and Kolmakoff, 1929).

Generally, piroplasms of wild carnivores appear to be incidental findings unrelated to disease. $B$. lotori has been described from raccoons (Procyon lotor) in the eastern USA (Anderson et al., 1981). The names $B$. procyoni and $B$. procyonis used previously for this organism by Frerichs and Holbrook (1970) are invalid, as "Piroplasma procyoni” (now regarded as B. procyoni) was used for an organism found in raccoon dogs (Nyctereutes procyonides) in Asia (Chobotar'ov, 1938).

Prevalence of B. cynicti infection in three yellow mongoose (Cynictis penicillata) populations in the north-eastern part of South Africa, as determined by blood smear examination, ranged from $72 \%$ to $96 \%$ (Penzhorn and Chaparro, 1994). The tendency of yellow mongooses to live in small clans frequenting permanent burrow systems could facilitate the transmission of $B$. cynicti by ticks and could account for the high prevalence of infection. Deleterious effects of the parasites on the mongooses are unknown, but Neitz (1938) found signs of anemia, with anisocytosis, 
polychromasia and erythrophagocytosis of the parasitized cells, on one of the smears that he examined.

All the lions examined in Kruger National Park (KNP), South Africa, harboured small piroplasms in their erythrocytes (Lopez-Rebollar et al., 1999). A similar situation was reported in Serengeti National Park in Tanzania (Averbeck et al., 1990). Although the KNP piroplasms resembled $B$. felis, they were serologically distinct (Lopez-Rebollar et al., 1999) and were subsequently characterized and described as a new species, B. leo (Penzhorn et al., 2001). There are, as yet, no reports of clinical babesiosis in free-ranging lions in South Africa or elsewhere. That does not necessarily rule it out altogether, as fresh lion carcasses are hardly ever found. Blood smears of a cat experimentally infected with $B$. leo remained negative for 42 days after infection, at which time the cat was splenectomized. Parasites appeared in the blood smears 8 days later. Parasitemia peaked at 45\%, 30 days after splenectomy. The only clinical sign observed in the cat was slight anemia. The parasitemia responded well to standard treatment for feline babesiosis. Piroplasms were seen on blood smears of a leopard 2 months after experimental infection. The leopard also seroconverted, but did not show any clinical signs of disease.

Babesia-related mortalities have been reported in various black rhinoceros (Diceros bicornis) populations in Kenya (Brocklesby, 1967 and Mugera and Wandera, 1967) and Tanzania (McCullogh and Achard, 1960), which limited successful translocation efforts. Mortality due to babesiosis may be triggered by stress factors, since in most cases animals died soon after capture. B. bicornis, recently described from black rhinoceroses in East and South Africa, has been incriminated in causing mortality (Nijhof et al., 2003). However, 5/11 healthy black rhinoceroses sampled in South Africa harboured the parasite without any obvious untoward effects.

Endemic stability to babesiosis has been well studied in cattle. For the first few months, calves are protected by passive immunity acquired from the dam's colostrum. If the calves are infected between the ages of about 3 and 9 months, they develop a solid immunity without showing any clinical signs. Immunity will wane if the animal is immunocompromised. This stable situation requires a high prevalence of infection in cattle, as well as a large enough tick population to ensure that calves become infected during the critical period.

Although this has not been studied in wildlife populations, there are indications that, in general, a similar endemically stable situation may exist. This could have major implications in the translocation of animals. Animals bred in captivity, which often occurs with so-called endangered species, may not be exposed to their natural parasites and will therefore not build up immunity. If these animals are then introduced into the wild to augment dwindling natural populations or to establish new ones, they could succumb to these parasites, nullifying the effort. Artificial infection of these animals with the specific parasite and follow-up treatment with anti-Babesia compounds would be a practical solution.

B. capreoli, described from the roe deer (Capreolus capreolus) (Enigk and Friedhoff, 1962) occurs widespread (Blancou, 1983) and causes fatalities in this species (Ivanics, 1982). Ixodes ricinus is the vector (Nikolskii and Pozov, 1972). The susceptibility of red deer (C. elaphus) and fallow deer (Dama dama) to B. capreoli has been investigated (Enigk and Friedhoff, 1963b). It should be noted that $B$. moravica was described from a roe deer with clinical piroplasmosis (Ullrich, 1940). This may be a synonym for B. capreoli. A Babesia from red deer (C. elaphus), 
isolated and characterized but not named (Adam et al., 1976), is now regarded as B. capreoli (Blewett and Adam, 1978).

After early reports of a Babesia in white-tailed deer (Odocoileus virginianus) (Spindler et al., 1958), B. odocoilei was isolated and described as a new species (Emerson and Wright, 1968 and Emerson and Wright, 1970). Artificial infection of a splenectomized white-tailed deer led to hemolytic anemia (Perry et al., 1985). Stage-to-stage transmission (nymph to adult) of $B$. odocoilei by Ixodes scapularis has been demonstrated (Waldrup et al., 1990). Serological prevalence in white-tailed deer was found to be $34 \%$ in Texas and $73 \%$ in Oklahoma, while deer less than 12 months old had significantly lower prevalence than other age classes (Waldrup et al., 1989). In Texas, seroconversion occurred during October-December, possibly continuing to January and February, strengthening the case for $I$. scapularis being a major vector (Waldrup et al., 1992). B. odocoilei has also been isolated from elk (C. elaphus) and caribou (Holman et al., 2000), while a genotypically distinct Babesia species has been isolated from caribou in the USA (Holman et al., 2002).

\section{Potential impact of Babesia infections on conservation actions}

Many wild animals, especially ungulates, are captured for translocation to establish new populations or augment existing ones. In ex situ conservation attempts, captive-bred animals are released into the wild. Well-meaning individuals also sometimes return hand-reared wild animals to the wild. All of these actions can create conditions favourable for the development of clinical babesiosis in the animals concerned, either through stress-mediated recrudescence of latent infections or though infection of naive animals.

The following is a case scenario: nine adult sable antelope were exported from a zoo in Germany to a game ranch in South Africa (McInnes et al., 1992). After arrival, the imported antelope were kept in pens on the ranch. During this time a wild-caught sable antelope that originated from an area where $B$. irvinesmithi is known to occur in the sable antelope population was held in an adjacent enclosure. This animal previously had been held in one of the pens used for the imported animals. No tick-control measures were implemented. Two imported antelopes died of acute babesiosis about 2 months after arrival on the ranch. The remaining animals were prophylactically treated with imidocarb diproprionate, and no further deaths occurred. The source of infection for the imported sable antelope is a matter of speculation. The most likely source of infection was the local animal that had been kept in the same pens later occupied by the imported animals. It is not unreasonable to speculate that ticks engorging on this animal had become infected, dropped off, moulted to the next instar and/or oviposited. The next instar/generation of ticks then fed on the imported sable and transmitted the infection to them. If B. irvinesmithi could be isolated from sable antelope, a stabilate could be prepared and used as a crude vaccine for imported animals. This will be the classical “infection and treatment” method.

"Return to the wild" of hand-reared animals should also be approached with caution. Although clinical babesiosis has not been recorded in lions, the famous lioness "Elsa" was reported to have died of babesiosis (Barnett and Brocklesby, 1968). Elsa was born in the wild, but had been handreared. Eventually, Elsa and her cubs were introduced to an area with a resident lion population that resented the intrusion. Elsa had been severely mauled by other lions on two occasions during the 4 months before she died (Adamson, 1962). In retrospect, it is clear that Elsa must have been 
severely stressed, which would have impacted on her immunocompetence. This could be the reason why she succumbed to an infection that a healthy lion would have tolerated.

The stress of capture and captivity can also cause latent infections to flare up. Dennig (1966) reported fatal equine piroplasmosis, caused by B. equi, in newly captured Grevy's zebras (Equus grevyi) in Kenya. He stated that the owner of the zebras and another trapper from Uganda estimated that they lost $20-25 \%$ of all their zebra catch from this disease, usually in the first 2-3 weeks after capture. The mortalities ascribed to babesiosis in black rhinos, discussed previously, also appeared to be linked directly to stressful situations. It may therefore be wise to attempt prophylactic treatment of the animals to prevent precipitation of disease. As dosages of prophylactic compounds have not been determined for wildlife, the only alternative would be extrapolating information from related domestic animals, and to proceed with caution.

\section{Conclusions}

Although some, generally well-studied, Babesia spp. commonly found in domestic animals have been reported from wild ungulates and carnivores closely related to their domestic counterparts, this would appear to be the exception to the rule. Exceptions may occur where wild animals are held in captivity. Under these conditions, infection of wild animals with Babesia spp. from domestic animals may well prove fatal. Indications are that wild animals have their own Babesia spp., with varying degrees of host specificity, and that endemic stability generally prevails. Various stressors, for instance capture and temporary captivity, may precipitate clinical babesiosis, caused by usually benign parasites, in wild animals. Prophylactic treatment of such animals may therefore be indicated.

Molecular biology is an invaluable tool for studying Babesia spp. in wild animals. As far as possible, new species should not be described solely on molecular evidence, but morphology, host-parasite interaction and biological factors, such as vectors involved, should also be taken into account. In wild animals the latter information may not always be readily available and may prove virtually impossible to acquire.

By default, extant phylogenetic trees are largely based on Babesia spp. from domestic animals, with some species from wild animals included. There can be no doubt that these Babesia species represent the proverbial tip of the iceberg, and that phylogenetic relationships become clearer as more and more Babesia spp. from wildlife are added. This process should continue apace. In a number of papers isolation and/or partial molecular characterisation of Babesia spp. from wild animals are reported. If this process is taken to its logical conclusion, i.e. formal description of species, overall understanding of the phylogeny of these piroplasms will be enhanced.

\section{References}

Adam et al., 1976 K.M.G. Adam, D.A. Blewett, D.W. Brocklesby and G.A.M. Sharman, The isolation and characterization of a Babesia from red deer (Cervus elaphus), Parasitology $\mathbf{7 3}$ (1976), pp. 1-11. 
Adamson, 1962 J. Adamson, Living free, Collins \& Harvill, London (1962).

Anderson et al., 1981 J.F. Anderson, L.A. Magnarelli and A.J. Sulzer, Racoon babesiosis in Connecticut, USA: Babesia lotori sp. n, J. Parasitol. 67 (1981), pp. 415-417.

Averbeck et al., 1990 G.A. Averbeck, K.E. Bjork, C. Packer and L. Herbst, Prevalence of haematozoans in lions (Panthera leo) and cheetah (Acinonyx jubatus) in Serengeti National Park and Ngorongoro Crater, Tanzania, J. Wildl. Dis. 26 (1990), p. 392.

Barnett and Brocklesby, 1968 S.F. Barnett and D.W. Brocklesby, Some piroplasms of wild animals, Symp. Zool. Soc. Lond. 24 (1968), pp. 159-176.

Bédier, 1924 E. Bédier, Piroplasme de la mangouste d'Afrique Herpestes calera Erxleben, C. $R$. Hebd. Séanc. Mém. Soc. Biol. 90 (1924), pp. 415-417.

Bigalke et al., 1970 R.D. Bigalke, M.D. Keep, P.J. Keep and J.H. Schoeman, A large Babesia sp. and a Theileria-like piroplasm of the square-lipped rhinoceros, J. S. Afr. Vet. Med. Assoc. 41 (1970), pp. 292-294.

Bigalke et al., 1972 R.D. Bigalke, M.D. Keep and J.H. Schoeman, Some protozoan parasites of tragelaphine antelopes in South Africa with special reference to a Babesia sp. in a bushbuck and a Trypanosoma theileri-like parasite in a nyala, Onderstepoort J. Vet. Res. 39 (1972), pp. 225-228.

Biocca and Corradetti, 1952 E. Biocca and A. Corradetti, Babesia missirolli, n. sp., parassita del tasso (Meles meles), Riv. Parassitol. 13 (1952), p. 17.

Blancou, 1983 J. Blancou, Serologic testing of wild roe deer (Capreolus capreolus L.) from the Trois Fontaines forest region of eastern France, J. Wildl. Dis. 19 (1983), pp. 271-2731.

Blewett and Adam, 1978 Blewett, D.A., Adam, K.M.G., 1978. Babesia capreoli (Enigk and Friedhoff, 1963), in red deer in Scotland. In: Wilde, J.K.H. (Ed.), Tick-borne Diseases and their Vectors. Edinburgh Univ. Press, pp. 377-378.

Brocklesby, 1967 D.W. Brocklesby, A Babesia species of the black rhinoceros, Vet. Rec. 80 (1967), p. 484.

Brocklesby and Campbell, 1963 D.W. Brocklesby and H. Campbell, A Babesia of the African elephant, E. Afr. Wildl. J. 1 (1963), p. 19.

Brocklesby and Vidler, 1965 D.W. Brocklesby and B.O. Vidler, Some parasites of East African wild animals, E. Afr. Wildl. J. 3 (1965), pp. 120-122.

Brumpt, 1920 E. Brumpt, Les piroplasmes des bovidés et leurs hôtes vecteurs, Bull. Soc. Pathol. Exot. 13 (1920), pp. 416-460.

Büscher, 1988 G. Büscher, The infection of various tick species with Babesia bigemina, its transmission and identification, Parasitol. Res. 74 (1988), pp. 324-330. 
Carmichael and Hobday, 1975 I.H. Carmichael and E. Hobday, Blood parasites of some wild Bovidae in Botswana, Onderstepoort J. Vet. Res. 42 (1975) (2), pp. 55-62.

Carpano, 1934 M. Carpano, Sur les piroplasmoses carnassiers et sur un nouveau piroplasme des félins (Babesiella felis chez le puma: Felis concolor), Bull. Tech. Sci. Serv., Min. Agric., Egypt. 137 (1934), pp. 1-26.

Carpano, 1939 M. Carpano, Sui piroplasmidi del cheiloni e su una nuova specie rinvenute nelle tartughe., Nuttalia guglielmi, Riv. Parasitol. 3 (1939), pp. 267-276.

Chambers, 1921 F. Chambers, Piroplasmosis of the reindeer, Vet. J. 77 (1921), pp. 415-419.

Chobotar'ov, 1938 R.S. Chobotar'ov, Description of Piroplasma of raccoon dogs-Piroplasma procyoni n. sp., Nauk. Zap. Kiev. Vet. Inst. 1 (1938), p. 158.

Clark and Zetek, 1925 H.C. Clark and J. Zetek, Tick biting experiments in bovine and cervine piroplasmosis, Am. J. Trop. Med. 5 (1925), pp. 17-26.

Colly and Nesbit, 1992 L.P. Colly and J.W. Nesbit, Fatal acute babesiosis in a juvenile wild dog (Lycaon pictus), J. S. Afr. Vet. Ass. 63 (1992), pp. 36-38.

Davis, 1929 L.J. Davis, On a piroplasm of the Sudanese wild cat (Felis ocreata), Trans. R. Soc. Trop. Med. Hyg. 22 (1929), pp. 523-534.

De Mello et al., 1923 F. De Mello, F. Rubello, S. Paes and C. d’Almeida, Sur un piroplasmide parasite du Bos brachycerus d'Angola (C. R. $1^{\mathrm{er}}$ ), Cong. Med. Trop. Afr. Occid., Luanda (1923) p. 527.

Dennig, 1966 H.K. Dennig, The isolation of Babesia species from wild animals, Proceedings of the First International Congress Parasitology (1966), pp. 262-263.

Dennig, 1967 H.K. Dennig, Eine unbekannte Babesienart beim Jaguarundi (Herpailurus yaguaroundi), Kleintierpraxis 12 (1967), pp. 146-152.

Dennig and Brocklesby, 1972 H.K. Dennig and D.W. Brocklesby, Babesia pantherae new species, a piroplasm of the leopard Panthera pardus, Parasitology 64 (1972), pp. 525-532.

De Smet and Lips, 1955 R.M. De Smet and M. Lips, Un nouveau Babesia du Katanga, Congo Belge, Ann. Soc. Belg. Med. Trop. 35 (1955), pp. 5-10.

Dissanaike, 1963 A.S. Dissanaike, On some blood parasites of wild animals in Ceylon, Ceylon Vet. J. 11 (1963), p. 73.

Emerson and Wright, 1968 H.R. Emerson and W.T. Wright, The isolation of a Babesia in whitetailed deer, Bull. Wildl. Dis. Assoc. 4 (1968), pp. 142-143. 
Emerson and Wright, 1970 H.R. Emerson and W.T. Wright, Correction, J. Wildl. Dis. 5 (1970), p. 519.

Enigk and Friedhoff, 1962 K. Enigk and K. Friedhoff, Babesia capreoli n. sp. beim Reh (Capreolus capreolus L.), Z. Tropenmed. Parasitol. 13 (1962), pp. 9-20.

Enigk and Friedhoff, 1963a K. Enigk and K. Friedhoff, Zur Wirtspezifität von Babesia bigemina (Piroplasmidea), Z. Tropenmed. Parasitol. 14 (1963), pp. 502-506.

Enigk and Friedhoff, 1963b K. Enigk and K. Friedhoff, Zur Empfänglichkeit von Rot- und Damhirsch für Babesia capreoli (Piroplasmidea), Z. Tropenmed. Parasitol. 14 (1963), pp. 57-62.

Evers et al., 2003 H.V. Evers, A.A. Kocan, M.V. Reichard and J.H. Meinkoth, Experimental Babesia gibsoni infection in coyotes (Canis latrans), J. Wildl. Dis. 39 (2003), pp. 904-908.

Ewing et al., 1964 S.A. Ewing, R.G. Buckner and B.G. Stringer, The coyote, a potential host for Babesia canis and Ehrlichia sp., J. Parasitol. 50 (1964), p. 704.

Ferrer et al., 1998a D. Ferrer, J. Castella, J.F. Gutierrez, S. Lavin and I. Marco, Seroprevalence of Babesia ovis in Spanish ibex (Capra pyrenaica) in Catalonia, northeastern Spain, Vet. Parasitol. 75 (1998), pp. 93-98.

Ferrer et al., 1998b D. Ferrer, J. Castella, J.F. Gutierrez, S. Lavin and I. Marco, Seroprevalence of Babesia ovis in mouflon sheep in Spain, J. Wildl. Dis. 34 (1998), pp. 637-639.

Findlay and Begg, 1977 C.R. Findlay and T.B. Begg, Redwater in American bison caused by Babesia major, Vet. Rec. 100 (1977), p. 406.

França, 1908 França, A., 1908. Cited, but not listed, by.

Frerichs and Holbrook, 1970 W.M. Frerichs and A.A. Holbrook, Babesia spp. and Haemobartonella spp. in wild mammals trapped at the Agricultural Research Center, Beltsville, Maryland, J. Parasitol. 56 (1970), p. 130.

Goff et al., 1993 W.L. Goff, D.A. Jessup, K.A. Waldrup, J.W. Thomford, R.A. Conrad, W.M. Boyce, J.R. Gorham and G.G. Wagner, The isolation and partial characterization of a Babesia sp. from desert bighorn sheep (Ovis canadensis nelsoni), J. Eukar. Microbiol. 40 (1993), pp. 237243.

Grewal, 1957 M.S. Grewal, Two new piroplasms, Babesia (Babesiella) heischi and Babesia (Babesia) hoarei from Peter's pigmy mongoose, Helogale undulata rufula (demonstrated by Professor Garnham), Trans. R. Soc. Trop. Med. Hyg. 51 (1957), pp. 290-291.

Heisch, 1952 R.B. Heisch, New piroplasms of a genet cat and a ground-squirrel from Kenya, Ann. Trop. Med. Parasitol. 46 (1952), pp. 150-154. 
Hinaidy, 1987 H.K. Hinaidy, Blutparasiten der wildlebenden Wiederkäuer Österreichs, J. Vet. Med. B 34 (1987), pp. 81-87.

Holbrook and Frerichs, 1970 A.A. Holbrook and W.M. Frerichs, Babesia mephitis sp. nov. (Protozoa: Piroplasmida): a hematozoan parasite of the striped skunk, Mephitis mephitis, J. Parasitol. 56 (1970), pp. 930-931.

Holman et al., 1994 P.J. Holman, T.M. Craig, D.L.D. Crider, K.R. Petrini, J. Rhyan and G.G. Wagner, Culture isolation and partial characterization of a Babesia sp. from a North American elk (Cervus elaphus), J. Wildl. Dis. 30 (1994), pp. 460-465.

Holman et al., 2000 P.J. Holman, J. Madeley, T.M. Craig, B.A. Allsopp, M.T.E.P. Allsopp, K.R. Petrini, S.D. Waghela and G.G. Wagner, Antigenic, phenotypic and molecular characterization confirms Babesia odocoilei isolated from three cervids, J. Wildl. Dis. 36 (2000), pp. 518-530.

Holman et al., 2002 P.J. Holman, P.K. Swift, R.E. Frey, J. Bennett, D. Cruz and G.G. Wagner, Genotypically unique Babesia spp. isolated from reindeer (Rangifer tarandus tarandus) in the United States, Parasitol. Res. 88 (2002), pp. 405-411.

Holman et al., 1993 P.J. Holman, K.A. Waldrup, R.E. Droleskey, D.E. Corrier and G.G. Wagner, In vitro growth of Babesia bovis in white-tailed deer (Odocoileus virginianus) erythrocytes, $J$. Parasitol. 79 (1993), pp. 233-237.

Hove et al., 1998 T. Hove, N. Sithole, D. Munodzana and S. Masaka, Isolation and characterization of a Babesia species from Rhipicephalus evertsi evertsi ticks picked off a sable antelope (Hippotragus niger) which died of acute babesiosis, Onderstepoort J. Vet. Res. 65 (1998), pp. 75-80.

Ivanics, 1982 E. Ivanics, A fatal case of babesiosis in a deer, Magyar Allotorvosok Lapja 37 (1982), pp. 625-626.

Jansen, 1952 B.C. Jansen, Babesia thomasi sp. nov., an intra-erythrocytic parasite of the Cape dassie [Procavia capensis (Pallas)], Onderstepoort J. Vet. Res. 25 (1952), pp. 3-6.

Karbe et al., 1979 E. Karbe, J.G. Grootenhuis, S. Kelley and L. Karstad, Experiments on the Babesia bigemina carrier state in East African buffalo Syncerus caffer and eland Taurotragus oryx, Tropenmed. Parasitol. 30 (1979), pp. 313-317.

Kjemtrup et al., 1995 A.M. Kjemtrup, J.W. Thomford, I.A. Gardner, P.A. Conrad, D.A. Jessup and W.M. Boyce, Seroprevalence of two Babesia spp. isolates in selected bighorn sheep (Ovis canadensis) and mule deer (Odocoileus hemionus) populations in California, J. Wildl. Dis. 31 (1995), pp. 467-471.

Kjemtrup et al., 2000 A.M. Kjemtrup, J. Thomford, T. Robinson and P.A. Conrad, Phylogenetic relationships of human and wildlife piroplasm isolates in the western United States inferred from the $18 \mathrm{~S}$ nuclear small subunit RNA gene, Parasitology 120 (2000), pp. 487-493. 
Krivkova, 1960 A.M. Krivkova, Novyi vid piroplazmy-Piroplasma meles sp. nov. iz krovi barsuka, Tr. Inst. Zool. Akad. Nauk Kaz. SSR 14 (1960), p. 42.

Langton et al., 2003 C. Langton, J.S. Gray, P.F. Waters and P.J. Holman, Naturally acquired babesiosis in a reindeer (Rangifer tarandus tarandus) herd in Great Britain, Parasitol. Res. 89 (2003), pp. 194-198.

Laveran, 1901 A. Laveran, Contributions à l'étude du Piroplasma equi, C.R. Séanc. Soc. Biol. 53 (1901), pp. 385-388.

Lebedeff and Tscharnotzky, 1911 W. Lebedeff and A. Tscharnotzky, Ein neuer Parasit im Blute des Iltis, Microsoma mustelae, Zbl. Bakteriol. Parasitenkd. Infektionskr. Hyg. Abt. 1 Orig. 58 (1911), pp. 625-631.

Leger and Leger, 1920 A. Leger and M. Leger, Piroplasme de la civette au Sénégal, Bull. Soc. Pathol. Exot. 13 (1920), pp. 649-652.

Leger and Bédier, 1922 M. Leger and E. Bédier, Piroplasme du renard d’Afrique, Fennecus dorsalis Gray, C. R. Hebd. Séanc. Mem. Soc. Biol. 87 (1922), pp. 934-935.

Leger and Bédier, 1923 M. Leger and E. Bédier, Plasmodium d’un mustélidé, Ictonyx zorilla, du Sénégal, C. R. Hebd. Séanc. Mem. Soc. Biol. 88 (1923), pp. 422-424.

Levine, 1971 N.D. Levine, Taxonomy of the piroplasms, Trans. Am. Microsc. Soc. 90 (1971), pp. 2-33.

Levine, 1984 N.D. Levine, Nomenclatural corrections and new taxa in the apicomplexan protozoa, Trans. Am. Microsc. Soc. 103 (1984), pp. 195-206.

Levine, 1988 N.D. Levine, The Protozoan Phylum Apicomplexa, vol. II, CRC Press, Boca Raton, FL, USA (1988) 154 pp..

Lopez-Rebollar et al., 1999 L.M. Lopez-Rebollar, B.L. Penzhorn, D.T. de Waal and B.D. Lewis, A possible new piroplasm in lions from the Republic of South Africa, J. Wildl. Dis. 35 (1999), pp. 82-85.

Marco et al., 2000 I. Marco, R. Velarde, J. Castellà, D. Ferrer and S. Lavín, Presumptive Babesia ovis infection in a Spanish ibex (Capra pyrenaica), Vet. Parasitol. 87 (2000), pp. 217-221.

Maronpot and Guindy, 1970 R.R. Maronpot and E. Guindy, Preliminary study of Babesia gibsoni Patton in wild carnivores and domesticated dogs in Egypt, Am. J. Vet. Res. 31 (1970), pp. 797799.

Martinaglia, 1930 G. Martinaglia, Red-water (babesiosis) in a sable antelope, J. S. Afr. Vet. Med. Assoc. 1 (1930) (4), pp. 41-42. 
Martinaglia, 1936 Martinaglia, G., 1936. Some considerations regarding the health of wild animals in captivity. Rep. Dir. Abattoir, Livestock \& Vet. Serv. Ice \& Cold Storage 1935/36 no. 26, pp. 30-33.

McCullogh and Achard, 1960 B. McCullogh and P.L. Achard, Mortalities associated with capture, translocation, trade and exhibition of black rhinoceroses, Int. Zoo Yb. 9 (1960), pp. 184195.

McInnes et al., 1992 E.F. McInnes, C.G. Stewart, B.L. Penzhorn and D.G.A. Meltzer, An outbreak of babesiosis in imported sable antelope (Hippotraguis niger), J. S. Afr. Vet. Assoc. 62 (1992), pp. 30-32.

Mehlhorn and Schein, 1998 H. Mehlhorn and E. Schein, Redescription of Babesia equi Laveran, 1902 as Theileria equi Mehlhorn, Schein, Parasit. Res. 84 (1998), pp. 467-475.

Mudaliar et al., 1950 S.V. Mudaliar, G.R. Acahry and V.S. Alwar, On a species of Babesia in an Indian wild cat, Ind. Vet. J. 26 (1950), pp. 391-395.

Mugera and Wandera, 1967 G.M. Mugera and J.G. Wandera, Degenerative myopathies in East African domestic and wild animals, Vet. Rec. 80 (1967), pp. 410-413.

Nagar et al., 1979 S.K. Nagar, V.K. Saxena and K. Kumar, Studies on small mammals of Delhi Zoological Park as possible source of babesiosis infection among white tigers in the zoo, $J$. Commun. Dis. 10 (1979), pp. 175-178.

Neitz, 1931 W.O. Neitz, Blood parasites of game in Zuluand, Rep. Dir. Vet. Serv. An. Ind., S. Afr. 17 (1931), pp. 45-60.

Neitz, 1938 W.O. Neitz, The occurrence of Nuttalia cynicti sp. nov. in the yellow mungoose (sic.) Cynictus (sic.) penicillata in South Africa, Onderstepoort J. Vet. Sci. An. Ind. 10 (1938), pp. $37-40$.

Neitz, 1965 W.O. Neitz, A checklist and hostlist of the zoonoses occurring in mammals and birds in South Africa, Onderstepoort J. Vet. Res. 32 (1965), pp. 189-374.

Neitz and Steyn, 1947 W.O. Neitz and H.P. Steyn, The transmission of Babesia canis (Piana and Galli-Valerio, 1895) to the black-backed jackal [Thos mesomelas (Schreber)], with a discussion on the classification of the piroplasms of the Canidae, J. S. Afr. Vet. Med. Assoc. 18 (1947), pp. $1-12$.

Nijhof et al., 2003 A. Nijhof, B.L. Penzhorn, G. Lynen, J.O. Mollel, C. Bekker and F. Jongejan, Babesia bicornis sp. n. and Theileria bicornis sp.n.: tick-borne parasites associated with mortality in the black rhinoceros (Diceros bicornis), J. Clin. Microbiol. 41 (2003), pp. 2249-2254.

Nikolskii and Pozov, 1972 S.M. Nikolskii and S.A. Pozov, Ixodes ricinus ticks as carriers of Babesia capreoli in the roe deer (in Russian), Veterinariya (Moscow) 4 (1972), p. 62. 
Nilsson et al., 1965 O. Nilsson, M. Nordkvist and L. Ryden, Experimental Babesia divergens infection in reindeer (Rangifer tarandus), Acta Vet. Scand. 6 (1965) (4), pp. 353-359.

Nuttall, 1910 G.F.H. Nuttall, On haematozoa occurring in wild animals in Africa. 1. Piroplasma rossi N. Sp. and Haemogregarina canis adusti N. Sp. found in the jackal, Parasitology 3 (1910), pp. 108-116.

Ono and Kondo, 1923 S. Ono and S. Kondo, Studies on rinderpest in deer (Cervus sika) and changes in the blood of infected animals, J. Jpn. Soc. Vet. Sci. 2 (1923), pp. 135-161.

Patton, 1910 W.S. Patton, Preliminary report on a new piroplasm (“Piroplasma Gibsoni” sp. nov.) found in the blood of hounds of the Madras Hunt and subsequently discovered in the blood of the jackal “Canis aureus”, Bull. Soc. Pathol. Exot. 3 (1910), pp. 271-281.

Peirce et al., 2001 M.A. Peirce, M.D. Anderson and B.L. Penzhorn, Piroplasmosis in the aardwolf (Proteles cristatus), Vet. Rec. 149 (2001), pp. 561-562.

Penzhorn and Chaparro, 1994 B.L. Penzhorn and F. Chaparro, Prevalence of Babesia cynicti infection in three populations of yellow mongooses (Cynictis penicillata) in the Transvaal, South Africa, J. Wildl. Dis. 30 (1994), pp. 557-559.

Penzhorn et al., 2001 B.L. Penzhorn, A.E. Kjemtrup, L.M. López-Rebollar and P.A. Conrad, Babesia leo n. sp. from lions in the Kruger National Park, South Africa, and its relation to other small piroplasms, J. Parasitol. 87 (2001), pp. 681-685.

Perry et al., 1985 B.D. Perry, D.K. Nichols and E.S. Cullom, Babesia odocoilei Emerson and Wright, 1970 in white-tailed deer, Odocoileus virginianus (Zimmermann), in Virginia, J. Wildl. Dis. 21 (1985), pp. 149-152.

Petrini et al., 1995 K.R. Petrini, P.J. Holman, J.C. Rhyan, S.J. Jenkins and G.G. Wagner, Fatal babesiosis in an American woodland caribou (Rangifer tarandus caribou), J. Zoo Wildl. Med. 26 (1995), pp. 298-305.

Rodhain, 1936 Rodhain, J., 1936. Cited by Levine (1988), but paper not listed.

Rukhlyadev and Abramova, 1956 D.P. Rukhlyadev and O.M. Abramova, Gemosporidii u zubrov, Tr. Inst. Zhivotnovod. Dagest. Fil. Akad. Nauk SSSR 3 (1956), p. 42.

Salabarria et al., 1981 F.F. Salabarria, A. Godshaev and T. Jimenez, Proceso hemolitico agudo en bisontes (Bison bison) causada por Babesia argentina, Rev. Cub. Cienc. Vet. 12 (1981), pp. 165170.

Schoop and Dedié, 1938 G. Schoop and K. Dedié, Uebertragung von Babesia canis auf Füchse, Deut. Tierärtzl. Wochschr. 46 (1938), pp. 88-90. 
Shone and Philip, 1960 D.K. Shone and J.R. Philip, The susceptibility of the African bushpig, Potamochoerus porcus maschona, Lönnberg, to infection with Babesia trautmanni, J. S. Afr. Vet. Med. Assoc. 31 (1960), pp. 451-453.

Spindler et al., 1958 L.A. Spindler, R.W. Allen, L.S. Diamond and J.C. Lotze, Babesia in a white-tailed deer, J. Protozool. 5 (1958), p. 8.

Stewart et al., 1992 C.G. Stewart, R.H. Keffen, C. McCrindle, A.N. Duncan and D.T. De Waal, Babesia trautmanni infection in a warthog (Phacochoerus aethiopicus), J. S. Afr. Vet. Assoc. 63 (1992), p. 98.

Thomas et al., 1982 S.E. Thomas, D.E. Wilson and T.E. Mason, Babesia, Theileria and Anaplasma spp. infecting sable antelope, Hippotragus niger (Harris, 1838) in Southern Africa, Onderstepoort J. Vet. Res. 49 (1982), pp. 163-166.

Thomford et al., 1993 J.W. Thomford, P.A. Conrad, W.M. Boyce, P.J. Holman and D.A. Jessup, Isolation and in vitro cultivation of Babesia parasites from free-ranging desert bighorn sheep (Ovis canadensis nelsoni) and mule deer (Odocoileus hemionus) in California, J. Parasitol. 79 (1993), pp. 77-84.

Ullrich, 1940 K. Ullrich, Ein Fall von Piroplasmose beim Rehwild, Tierärtzl. Rdsch. 46 (1940), pp. 331-334.

Van den Berge, 1937 L. Van den Berge, Une piroplasmide nouveau, Nuttalia alberti n. sp. chez une hyène du parc national Albert (Congo Belge), Bull. Soc. Pathol. Exot. 30 (1937), pp. 271272.

Van Heerden, $1980 \mathrm{~J}$. Van Heerden, The transmission of Babesia canis to the wild dog Lycaon pictus (Temminck) and black-backed jackal (Canis mesomelas) Schreber, J. S. Afr. Vet. Assoc. 51 (1980), pp. 119-120.

Waldrup et al., 1990 K.A. Waldrup, A.A. Kocan, R.W. Barker and G.G. Wagner, Transmission of Babesia odocoilei in white-tailed deer (Odocoileus virginianus) by Ixodes scapularis (Acari: Ixodidae), J. Wildl. Dis. 21 (1990), pp. 149-152.

Waldrup et al., 1989 K.A. Waldrup, A.A. Kocan, T. Qureshi, D.S. Davis, D. Baggett and G.G. Wagner, Serological prevalence and isolation of Babesia odocoilei among white-tailed deer (Odocoileus virginianus) in Texas and Oklahoma, J. Wildl. Dis. 25 (1989), pp. 194-210.

Waldrup et al., 1992 K.A. Waldrup, J. Moritz, D. Baggett, S. Magyar and G.G. Wagner, Monthly indicence of Theileria cervi and seroconversion to Babesia odocoilei in white-tailed deer (Odocoileus virginianus) in Texas, J. Wildl. Dis. 28 (1992), pp. 457-459.

Wenyon, 1926 C.M. Wenyon, Protozoology, vol. 2, Bailiere/Tindall \& Cox, London (1926). 
Wenyon and Hamerton, 1930 C.M. Wenyon and A.E. Hamerton, Piroplasms of the west African civet cat (Viverra civetta) and the bay lynx (Felis rufus) of North America, Trans. R. Soc. Trop. Med. Hyg. 24 (1930), pp. 7-8.

Wilson and Hirst, 1977 D.E. Wilson and S.M. Hirst, Ecology and factors limiting roan and sable antelope populations in South Africa, Wildl. Monogr. 54 (1977), pp. 1-111.

Yakimoff and Kolmakoff, 1929 W.L. Yakimoff and W.D. Kolmakoff, Zur Frage über die Piroplasmose des Renntieres, Arch. Protistenk. 66 (1929), pp. 322-328.

Yakimoff and Shokor, 1916 W.L. Yakimoff and N.I. Shokor, Un cas de piroplasmose des loups au Turkestan, Arkh. Vet. Nauk. St. -Peterb. 46 (1916), p. 343.

Young et al., 1973 E. Young, F. Zumpt, J. Boomker, B.L. Penzhorn and B. Erasmus, Parasites and diseases of Cape mountain zebra, black wildebeest, mountain reedbuck and blesbok in the Mountain Zebra National Park, South Africa, Koedoe 16 (1973), pp. 77-81.

Zaugg and Kuttler, 1987 J.L. Zaugg and K.L. Kuttler, Experimental infections of Babesia bigemina in American bison, J. Wildl. Dis. 23 (1987), pp. 99-102.

Zweygarth et al., $200 \underline{2}$ E. Zweygarth, L.M. Lopez-Rebollar and P. Meyer, In vitro isolation of equine piroplasms derived from Cape Mountain zebra (Equus zebra zebra) in South Africa, Onderstepoort J. Vet. Res. 69 (2002), pp. 197-200. 